\title{
History and Present Status of the Centralization of the Libraries of the Oregon State System of Higher Education
}

Mr. Carlson is director of libraries, Oregon State System of Higher Education.

W

HEN the State-supported institutions of higher education in Oregon were centralized in 1931 under the direction of a single chancellor there was also set up, as a part of that centralization, an administrative unification of all the libraries of the several institutions. This library centralization, largely conceived by Corneila Marvin Pierce, then Oregon State librarian and a member of the first centralized State Board of Higher Education, was made an integral part of the Administrative Code set up and adopted by the Board.

Because this was the first time that any State had undertaken to unify the libraries of its State-supported higher institutions of education, the unification naturally attracted a good deal of attention among students of library administration and among many practicing librarians too. One reflection of this interest is the Master's thesis prepared at the Graduate Library School of the University of Chicago by Mildred Hawksworth Lowell, formerly librarian of Eastern Oregon College of Education. Mrs. Lowell's thesis, published by the Oregon State System of Higher Education in 1942, was devoted to the unification of libraries everywhere but devoted major attention to the Oregon libraries and the Oregon centralization. This thesis was accurately documented and presented the Oregon unification exactly as constituted by the Board in its Administrative Code. The unification of the libraries has not, however, from the beginning, - functioned as set up on paper. The fact that the centralization of the libraries has differed so extensively in practice from the centralization as stipulated by the Board has quite understandably created some misunderstanding in library circles. For this reason, this brief explanation of how the centralization has evolved and is now functioning is presented :

Salient features of the unification of the libraries, as set up in $193 \mathrm{I}$, were:

I. A director of libraries (also to serve as librarian of the State College at Corvallis) to be responsible for the policies and organization of the division of service, staff personnel, library instruction, preparation of the budget, and allocation of funds on the approval of the administrators of the several institutions.

2. A librarian on each campus working under the director.

3. A free circulating book stock, including the transfer of books between institutions as required, upon authorization of the director, in consultation with librarians and deans of the schools concerned.

4. A common book fund to be allocated by 
the director and approved by the various presidents.

5. Centralization of the ordering and cataloging of all materials acquired.

6. Instruction in the use of the library on each campus and the appointment of a system supervisor of library instruction.

Several features of this unification have never been carried out as originally planned by the Board. At no time has the director prepared budgets and allocated funds to the various libraries, nor directed the work of the head librarians in anything but an advisory way, nor established or attempted to establish a common book fund for the allocation to the various libraries as specified by the Board's Administrative Code. Neither has the freely circulating book stock, including transfer of books between the institutions, as required, worked out in practice. One attempt to achieve such a transfer of books was not successful and constituted a considerable source of irritation between the two major institutions for a considerable period of years. Neither was instruction in the use of the library on each campus ever undertaken under the supervision of the director of libraries.

The centralization of the ordering (but not the cataloging) of books has been carried out but not to the degree and complete extent envisaged in the original Board directive.

The Central Library Office was established in the State College Library in Corvallis with a small central staff. A first step in the centralization, was, of course, the creation, in the Central Library office, of a complete author union catalog of all the books in the system libraries. For a time some members of the University of Oregon Order Department at Eugene were assigned to the Corvallis office. It soon became apparent that the volume and degree of ordering carried out by the University Library was too extensive to be satis- factorily handled in a branch office some forty miles distant. All order work as it pertained to the University Library was therefore, at an early date, returned to the Eugene campus. The Central Library office did, however, continue to handle the complete order process for the College of Education Libraries. This centralized ordering, as well as centralized bookkeeping for all the libraries of the system has, throughout the years, been carried forward with signal success.

In effect, the unification of the Oregon libraries has differentiated more and more in practice from the unification as originally set up by the Board. The evolution has been definitely toward a group of autonomous libraries with the director of libraries serving more in an advisory and coordinating capacity for all the library affairs of the system, rather than as the central administrative office specified by the Board in 1931 .

In recognition of the fact that the Oregon unification has never functioned as set up on paper, the librarians of the system have undertaken, on their own initiative, a revision of the Code statement placing it in harmony with the actual functioning of the centralization as it has evolved over the years. This revision was made by the $\mathrm{Li}^{-}$ brary Council of the system, an agency set up 'in the late I930's as an informational and policy group of the combined libraries. As is to be expected, the revision undertaken in the fall of 1950 was not achieved without extensive and spirited discussion. The revised statement, as agreed upon in the Council, was referred to the Chancellor in the spring of $195 \mathrm{I}$. It was approved by him and is now a part of the official administrative Code of the State Board of Higher Education. The revision, as will be noted in the draft set forth below, relieves the director of libraries of all direct administra- 
tive responsibility for the operation of various libraries of the system, a responsibility which, in effect, he never exercised. It does retain the director, in a vital and important sense, as a coordinating and integrating officer and advisor to the Chancellor, in all matters pertaining to the libraries.

\section{Libraries}

a. It is the intent of the Board to maintain a closely coordinated and integrated system of autonomous libraries through which unnecessary duplication in materials, services, and procedures will be avoided and the library facilities and resources of the entire system will be readily available to all faculty members and students of the institutions under the control of the Board. Coordination of system-wide library development, processes and services will be achieved through:

(I) A chief librarian at each institution who, while. working in close cooperation with the other libraries of the system and the Central Library Office, shall be directly responsible to his institutional executive officer for all phases of operation of the institutional library or libraries.

(2) A director of libraries who will also serve as chief librarian of one of the institutional libraries. It shall be his duty to administer the work of the Central Library Office; to be alert to the avoidance of unnecessary duplication among the libraries, either in resources or services; to coordinate and integrate the development and work of the libraries wherever possible; to direct the work and deliberations of the Library Council; to make biennial reports on the development, operation and problems of the libraries to the Chancellor, and such annual and special reports as may, from time to time be required; to maintain and cumulate, monthly and annually, statistics for the libraries; to serve as an adviser to all chief librarians in the system and to the institutional executive officers whenever they may so desire; and to advise and counsel the Chancellor on all system-wide problems and undertakings touching the operation of the libraries.

(3) A Central Library Office, administered by the director of libraries. The function of this office will include:

(a) Responsibility for the centralized ordering of books for the three colleges of education and the General Extension Division, and for the other libraries at whatever times such centralization should be advantageous for them.

(b) Maintenance of centralized bookkeeping records for all the libraries of the system, furnishing each library, as frequently as it may require, a statement of its disbursements and financial status.

(c) Pooling of orders for all supplies and equipment, such as catalog cards, business forms and furniture on which quantity discounts may be obtained.

(d) Maintenance, in the Central Library Office, of a union author catalog of all books in the system libraries. Corollary to this an author catalog of all books in the State College Library will be maintained at the University Library and an author catalog of all books of medical interest in the State College and University Libraries will be maintained at the Medical School Library.

(4) A Library Council consisting of the Chancellor, the chief librarian of each institution, and the head order librarian of each institution, and the head order librarian of the Central Library Office. This Council will meet periodically to discuss problems of mutual concern 
and interest, and to develop plans for a free inter-lending of books among their respective institutions, and avoidance of unnecessary duplication.

b. The Board, in its original directive for centralization of library resources and services, adopted in 193I, set forth 'an ideal for a great common supply of books and other printed materials.' This ideal will continuously be the guide of the Central Library Office, the director of libraries, the chief librarians, and the Library Council.

The librarians of the Oregon State System of Higher Education take pleasure in having been able to achieve, in a spirit of friendship and mutual understanding, the complete revision of the Code set forth above. It is hoped that the revision, as here presented, will clarify the present status of the Oregon centralization and that this clarification will be of interest and value to library administrators as an indication of the evolution of the first notable effort of any state to coordinate, integrate, and centralize the development and operations of libraries of its State-supported institutions of Higher Education.

\section{Progress Report on Activities of the Joint Committee on Library Education}

The Joint Committee on Library Education of the Council of National Library Associations met at the International House, University of Chicago, on April 4, 1953. Representatives of eight library associations, five members at large, and four observers were present at the meeting. Mrs. Eileen R. Cunningham, librarian, Vanderbilt University School of Medicine, presided.

Edward N. Waters, chairman of the Subcommittee on Special Library Education, reported on the meeting held the preceding day at the International House and presented plans for publication of the studies dealing with suggested curricula in seven subject fields. Melvin J. Voigt is the editor. Members of the Joint Committee hope these reports will be used as a guide by a few library schools where a combination of circumstances makes it possible to plan adequately for training librarians in any one of these subject areas. Subsequent to publication of the outlines of curricula, the Subcommittee studies may be expanded to other fields not heretofore considered in detail.

At the request of the chairman, Jack Dalton outlined the present status of the accreditation program for library schools, emphasizing the events leading up to, and subsequent to, the issuance of Program Letter Number one from the National Commission on Accreditation. Unfortunately this letter went out twelve days after the fall meeting of the Joint Committee in Washington on October 25, 1952. The members, after hearing Mr. Dalton's report, commended the ALA Board of Education for Librarianship on their efficient handling of the situation and expressed their continued desire for the Joint Committee to support the Board and other interested groups in a firm accreditation program.

Dr. Maurice F. Tauber submitted a progress report of the Subcommittee on Examinations. Information concerning procedures in sixteen states indicated that no particular pattern as to content and form is followed. On the basis of replies received it was evident many state agencies were interested in receiving advice and aid in clarifying thir examination programs. It was the consensus of those present that further study of the problem should be referred to the Board of Education for Librarianship.

Dr. Frances Henne, in her report on program planning, suggested that the Joint Committee could serve as an informational and liaison center in educational matters for the various library groups which compose the CNLA and that each member should report at each meeting what his association is doing or would like to have done. In accordance with Resolution 2 of the Princeton Conference on Library Education, these reports would be submitted for publication in the AALS Newsletter.-Irene M. Strieby. 